\title{
Health effects associated with exposure to anaesthetic gases in Ontario hospital personnel
}

\author{
S S Guirguis, P L Pelmear, M L Roy, L Wong
}

\begin{abstract}
In a retrospective study (by questionnaire) of 8032 personnel exposed to anaesthetic gases in operating and recovery rooms in Ontario hospitals, and 2525 non-exposed hospital staff, the response was $\mathbf{7 8 \cdot 8 \%}$ for the exposed and $87 \cdot 2 \%$ for the unexposed personnel during the period 1981-5. Logistic regression analysis, with age and smoking standardised, showed that women in the exposed group had significantly increased frequencies of spontaneous abortion and their children had significantly more congenital abnormalities $(p<0.05)$. No chronic disease was significantly associated with the exposed group. These findings, together with similar ones from other studies, suggest that it is prudent to minimise exposure to waste anaesthetic gases.
\end{abstract}

Exposure of workers to waste anaesthetic gases in the operating and recovery rooms of hospitals is of concern because of the reported adverse effects of such gases on the health of personnel in this occupational group. A mortality study in 1968 on the causes of death among anaesthetists in the United States showed an increased death rate from lymphoid and reticuloendothelial malignancies. ${ }^{1}$ The authors did not rule out chance as a reason for the finding, however, and in a follow up study the findings were not supported. ${ }^{2}$ Further study in 1977 among doctors in different specialties in the United Kingdom showed an excess of deaths from pancreatic cancer among full time but not among part time anaesthetists. ${ }^{3}$ Again, the authors suggested that the positive findings may have emerged by chance as a result of multiple comparisons.

Exposure to high concentrations of anaesthetics has been reported to affect health. Nitrous oxide concentrations as low as $50 \mathrm{ppm}$ caused measurable performance decrements in psychological tests taken by healthy male graduate students. ${ }^{4}$ Nitrous oxide may result in haematological change ${ }^{5}$ and abuse of

Health and Safety Support Services Branch, Ministry of Labour, Toronto, Ontario M7A 1T7, Canada S S Guirguis, P L Pelmear, M L Roy, L Wong nitrous oxide causes peripheral neuropathy. ${ }^{6}$ Anaesthetic concentrations of halothane may result in acute hepatitis with liver necrosis. ${ }^{78}$

Possible chronic effects studied in exposed populations include cancer, and liver and kidney disease, but the findings are inconsistent. ${ }^{9-11}$ Cohen and colleagues reported increased rates of cancer, hepatic disease and renal disease among the women in an operating room exposed group; doctors and nurses had a high prevalence of liver disease, but only nurses had a high prevalence of kidney disease. No increase in cancer was found among exposed men, but an increased prevalence of hepatic disease similar in magnitude to that in the women was found. ${ }^{9}$ In dentistry liver disease (but not cancer or kidney disease) was more prevalent in both male dentists and female chair side assistants compared with controls. Neuropathies were also common in this exposed group. ${ }^{10}$ The diagnosis of cancer among nurse anaesthetists was reported to be significantly higher than controls in another study. ${ }^{11}$

Reviews of the outcomes and significance of pregnancies among women occupationally exposed to waste anaesthetic gases and among wives of men similarly exposed have been published from various countries-namely the Soviet Union, ${ }^{12}$ Denmark, ${ }^{13}$ United States, ${ }^{9-11}$ United Kingdom, ${ }^{15-17}$ Finland, ${ }^{18}$ and Sweden. ${ }^{19}$ The results of all the studies were based on questionnaires or on birth and employment records that reported spontaneous abortions and complications of pregnancy. Some of these studies showed a positive relation between exposure to anaesthetics and the frequency of spontaneous abortions $^{912-15}$ but others did not. ${ }^{117}$ Likewise, the frequency of congenital abnormalities among the children of workers exposed to anaesthetic gases was high in some studies ${ }^{91517}$ but not in others. ${ }^{1319}$

The American Society of Anesthesiologists (ASA) ad hoc committee on the health of operating room personnel conducted a national study between 1972 and $1974 .{ }^{9}$ Questionnaires were mailed to 49585 operating room staff and a control group of 23911 non-operating room staff members of the American Academy of Pediatrics and the American Nurses' Association to determine whether outcomes of pregnancy such as spontaneous abortions and congenital abnormalities, and other chronic health effects could be attributed to exposure to waste anaesthetic gas. 
Returns from 29810 exposed and 10234 unexposed persons were analysed. After standardisation for age and smoking, women in the exposed group reported significantly increased frequencies of spontaneous abortions and congenital abnormalities. In addition, there was a significantly higher frequency of congenital malformations among children of the wives of exposed male nurses and technicians. The same questionnaire was used by others to investigate the possible effect of anaesthetics among dentists. ${ }^{10}$ They reported a significant increase in the frequency of spontaneous abortion among the wives of exposed dentists compared with controls, but the difference in the malformation rate was not significant. In a follow up study five years later an increased frequency of spontaneous abortions was found among the wives of dentists and also among women chair side assistants. As dentists commonly use nitrous oxide, these findings can be attributed to this anaesthetic. ${ }^{20}$

Results of several studies on animals provide supporting evidence for a causal relation; short term exposures to nitrous oxide were shown to be embryotoxic and teratogenic in rats, ${ }^{21-24}$ chicks, ${ }^{25} 26$ and hamsters, ${ }^{27}$ and reproductive effects were observed in gravid rats chronically exposed to nitrous oxide. $^{28-30}$ Chronic exposure to halothane caused ultrastructural changes in the liver cells of rats, with evidence of hepatotoxicity. ${ }^{3132}$ Overexposure to halothane was found to be embryotoxic or teratogenic or both in rats, ${ }^{33}$ guinea pigs, ${ }^{34}$ and chicks. ${ }^{35}$ Cleft palate was induced by halothane anaesthesia in C-57 beach mice. ${ }^{36}$

Despite the findings from animal studies and epidemiological reports, the question as to whether a causal relation exists between exposure to anaesthetics and effects on health among operating and recovery room workers remains essentially unanswered. Thus, this study was undertaken to determine if personnel exposed to anaesthetic gases in Ontario hospitals experienced health problems similar to those reported by the ASA ad hoc committee. The questionnaire of the USA, published in 1974 , was used together with a supplementary questionnaire that included an extended history (before the past 10 years) for information related to adverse reproductive outcomes.

\section{Population and methods \\ HOSPITALS}

Seventy five hospitals in the province of Ontario were selected as a representative sample of the 195 non-federal hospitals offering surgery in 1980 . The selection was weighted to provided representative distribution by geographic location including variations in local population density and size of hospital (total number of beds); general $v$ specialty (orthopaedic, paediatric, cancer) hospitals; teaching $v$ non- teaching hospitals; and public $v$ private hospital control.

\section{STUDY POPULATION}

All persons chronically exposed to waste anaesthetic gases (spending at least two hours a week in the operating room) in the 75 selected hospitals, as identified by the director of operating room nursing (or director of nursing in smaller hospitals), were considered to be potentially exposed. A total of $\mathbf{8 0 4 0}$ persons was included. Because of the possibility of an inadequate response rate, a random sample of the exposed personnel from the master list (one out of every five) was also identified for more intensive follow up.

An unexposed group was selected as a control from other departments of each hospital: a total of 2517 persons was finally included. Hence, the study population was 10557 persons.

\section{QUESTIONNAIRE}

A survey by questionnaire was conducted during the period 1981-5. The questionnaires were distributed to all personnel identified as potentially exposed and to the controls either directly, through the director of operating room nursing, or by mail. Mailing the questionnaires without prior contact with the hospitals was not possible because no comprehensive listings of operating room personnel were available except through them. The data were edited as received and the information from completed forms was entered into a computer for storage and retrieval. Personnel who had submitted incomplete forms were followed up by phone or interview to complete the questionnaire. Follow up of non-returns was done by phone or personal contact. In addition to the study carried out by questionnaire, an environmental study to evaluate the current occupational exposure to waste anaesthetic gases was conducted in these hospitals; these findings have been reported elsewhere. ${ }^{39}$

Confidentiality of information was always maintained and only coded information was used in the analysis. A 13 digit coding system was assigned to each questionnaire to identify the data collecting procedure (self administered, completed by interview, or a combination of both); the geographical location; the data of completion; and the occupation of the respondent.

The analysis was similar to that used in the United States national study. Rates for spontaneous abortion (loss of the product of conception before the 20th week of pregnancy) were based on the number of spontaneous abortions as reported by the exposed woman or by the male respondents for their spouses during the past 20 years; therapeutic abortions were not included. Congenital abnormality rates were 
based on the number of liveborn babies with one or more abnormalities per 100 liveborn babies born over the past 20 years. Disease rates were based on the number of cases diagnosed within the past 20 years per 100 female or male respondents only when they were preceded by exposure to anaesthetics. The "latency period" was not considered in the analysis. Rates were standardised and adjusted for both age and smoking at the time of pregnancy, for analysis of spontaneous abortions and congenital abnormalities, but only for age at the time of the survey in the analysis of various diseases.

Results were analysed according to the anaesthetic exposure of the respondent. This was estimated from information provided on the questionnaire (occupation and years of exposure) and from information provided by the concurrent hygiene study findings (average weekly duration of exposure for the various occupations).

\section{Results}

Questionnaires were distributed to 8032 hospital staff exposed to waste anaesthetic gases and 2525 unexposed hospital staff. Table 1 shows that the response rate for completion of the questionnaire was $\mathbf{7 8 . 8} \%$ for the exposed group, $\mathbf{9 0 . 8 \%}$ for the randomly selected exposed group, and $87.2 \%$ for the control group. In addition, table 1 shows the distribution of returned questionnaires by occupational groups. Doctors were more reluctant to respond than other groups. When followed up by telephone, as was necessary for the random sample, the response rate from doctors improved, but was still about $10 \%$ less than for other staff.

Table 2 shows the weekly exposure to anaesthetic gases by occupational group. The data were derived from the questionnaire and the hygiene study findings on average weekly exposure for the various occupations. ${ }^{39}$

A total of 16724 pregnancies was reported; 13068 by the exposed women and spouses of exposed men (including 2936 in the random group), and 3656 by the unexposed women and the spouses of unexposed men. Of the 13068 pregnancies reported by the exposed female workers and wives of exposed men 2836 occurred before exposure to anaesthetics and these were excluded from the analysis. Thus 10232 pregnancies in the exposed group and 2225 in the random sample were available for statistical analysis. Table 3 shows the results and the number of unknown results of pregnancy by occupational group. The mean number of pregnancies per person differed significantly between the exposed and unexposed groups (2.06 for the exposed and 1.66 for the unexposed groups). This may have been due to the younger control population (mean age 36.9 years for the unexposed and 40.8 years for the exposed groups). To overcome this problem analysis was based on age at the time of pregnancy. For male respondents all results refer to their spouses. Excluding the 57 unknown pregnancy results, spontaneous abortion was found to be significantly higher in the exposed group and the randomly selected exposed group than in the control group. The levels of significance did not change when analysis included the 57 as normal outcome.

Table 4 shows the association between reproductive effects and anaesthetic exposure adjusted for the effects of potential confounders by linear logistic regression as used in similar retrospective cohort studies. The adjusted odds ratio for spontaneous abortion was significant between exposed and unexposed female workers. The adjusted odds ratio for

Table 1 Distribution of returned questionnaires by occupational groups

\begin{tabular}{|c|c|c|c|c|c|c|}
\hline \multirow[b]{2}{*}{ Occupation } & \multicolumn{2}{|l|}{ Unexposed group } & \multicolumn{2}{|l|}{ Exposed group } & \multicolumn{2}{|l|}{ Random sample } \\
\hline & $\begin{array}{l}\text { No in } \\
\text { population }(\%)\end{array}$ & $\begin{array}{l}\% \\
\text { Response }\end{array}$ & $\begin{array}{l}\text { No in } \\
\text { population }(\%)\end{array}$ & $\begin{array}{l}\% \\
\text { Response }\end{array}$ & $\begin{array}{l}\text { No in } \\
\text { population }(\%)\end{array}$ & $\begin{array}{l}\% \\
\text { Response }\end{array}$ \\
\hline $\begin{array}{l}\text { Doctors } \\
\text { Nurses } \\
\text { Others } \\
\text { Total }\end{array}$ & $\begin{array}{l}479(21 \cdot 7 \%) \\
911(41.4 \%) \\
812(36.9 \%) \\
2202\end{array}$ & $\begin{array}{l}62 \cdot 2 \\
97 \cdot 4 \\
86 \cdot 8 \\
87 \cdot 2\end{array}$ & $\begin{array}{l}2373(37 \cdot 5 \%) \\
3038(47 \cdot 9 \%) \\
925(14 \cdot 6 \%) \\
6336\end{array}$ & $\begin{array}{l}67 \cdot 3 \\
90 \cdot 0 \\
88 \cdot 9 \\
78 \cdot 8\end{array}$ & $\begin{array}{l}560(38 \cdot 8 \%) \\
633(43 \cdot 9 \%) \\
250(17 \cdot 3) \\
1443\end{array}$ & $\begin{array}{l}84 \cdot 4 \\
96 \cdot 6 \\
95 \cdot 0 \\
90 \cdot 8\end{array}$ \\
\hline
\end{tabular}

Table 2 Occupational weekly exposure to anaesthetic gases by occupational group

\begin{tabular}{|c|c|c|c|}
\hline Occupation & Range of exposure time (h) & Mean & $S D$ \\
\hline $\begin{array}{l}\text { Anaesthetist } \\
\text { Scrub nurse } \\
\text { Operating room technician } \\
\text { Operating room circulating nurse } \\
\text { Orderly } \\
\text { Surgeon }\end{array}$ & $\begin{array}{l}3-65 \\
3-40 \\
27 \cdot 5-40 \\
3-40 \\
25-40 \\
2-42\end{array}$ & $\begin{array}{l}33 \cdot 2 \\
31 \cdot 4 \\
37 \cdot 2 \\
34 \cdot 1 \\
36 \cdot 8 \\
12 \cdot 8\end{array}$ & $\begin{array}{r}17 \cdot 0 \\
10 \cdot 2 \\
3 \cdot 5 \\
8 \cdot 6 \\
3 \cdot 4 \\
6 \cdot 2\end{array}$ \\
\hline
\end{tabular}


Table 3 Results of pregnancy by exposure to anaesthetics and occupationl group

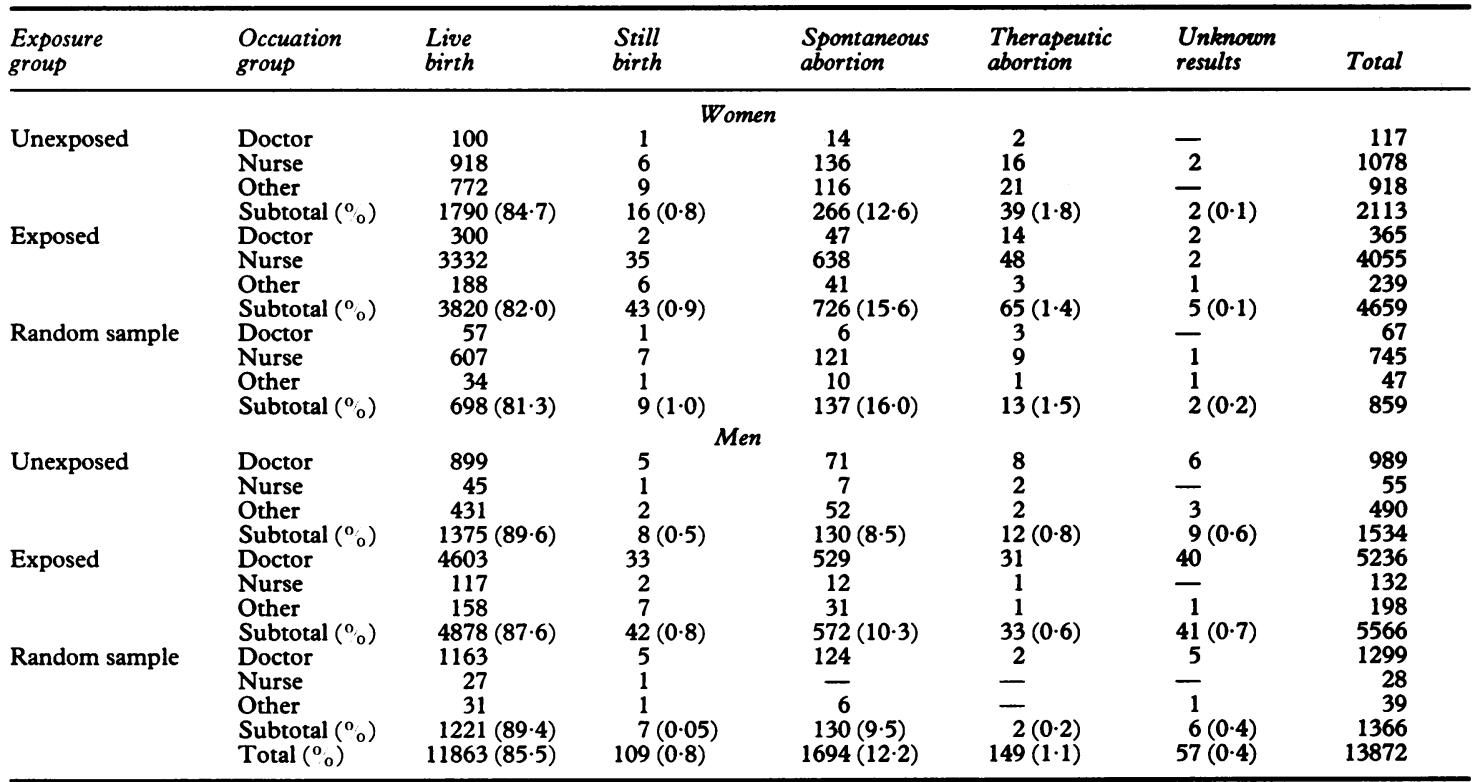

Table 4 Associations between reported reproductive effects and exposure to anaesthetics controlling for the effects of potential confounders by linear logistic regression among female workers in selected Ontario hospitals

\begin{tabular}{|c|c|c|c|}
\hline Independent variables & Description & $\begin{array}{l}\text { Adjusted } \\
\text { odds ratio } †\end{array}$ & $\begin{array}{l}95 \% \text { Confidence } \\
\text { interval }\end{array}$ \\
\hline $\begin{array}{l}\text { Anaesthetics exposure } \\
\text { Birth order } \\
\text { Age of mother at pregnancy } \\
\text { Cigarette consumption during } \\
\text { pregnancy } \\
\text { Alcohol consumption during pregnancy } \\
\text { Previous spontaneous abortion } \\
\text { Occupation } \\
\text { Occupation }\end{array}$ & $\begin{array}{l}\quad \text { Spontaneous abortion } \\
\text { Exposed/unexposed } \ddagger \\
\text { One increase } \\
\text { One year increase } \\
\text { Over } 20 \text { cigarettes a day/under } \\
20 \text { cigarettes/none } \\
\text { Yes/no } \\
\text { Yes/no } \\
\text { Doctors/others } \\
\text { Nurses/others }\end{array}$ & $\begin{array}{l}1.98^{\star} \\
1.12^{\star} \\
0.99 \\
1.06 \\
0.77^{\star} \\
1.96^{\star} \\
0.96 \\
1.00\end{array}$ & $\begin{array}{l}1.53-2.56 \\
1.03-1.21 \\
0.97-1.02 \\
0.91-1.25 \\
0.63-0.95 \\
1.53-2.51 \\
0.61-1.52 \\
0.74-1.36\end{array}$ \\
\hline $\begin{array}{l}\text { Anaesthetics exposure } \\
\text { Birth Order } \\
\text { Age of mother at pregnancy } \\
\text { Cigarette consumption during pregnancy }\end{array}$ & $\begin{array}{l}\text { Congenital abnormality } \\
\text { Exposed/unexposed } \ddagger \\
\text { One increase } \\
\text { One year increase } \\
\text { Over } 20 \text { cigarettes a day/under } \\
20 \text { cigarettes/none }\end{array}$ & $\begin{array}{l}2 \cdot 24^{\star} \\
1 \cdot 07 \\
0 \cdot 95^{\star} \\
0.98\end{array}$ & $\begin{array}{l}1.69-2.97 \\
0.97-1 \cdot 17 \\
0.92-0.97 \\
0.83-1 \cdot 17\end{array}$ \\
\hline $\begin{array}{l}\text { Alcohol consumption during pregnancy } \\
\text { Occupation } \\
\text { Occupation }\end{array}$ & $\begin{array}{l}\text { Yes/no } \\
\text { Doctors/others } \\
\text { Nurses/others }\end{array}$ & $\begin{array}{l}1.24 \\
1.50 \\
1.28\end{array}$ & $\begin{array}{l}1.00-1.52 \\
0.91-2.48 \\
0.90-1.83\end{array}$ \\
\hline
\end{tabular}

${ }^{\star} \mathrm{p}<0.05$.

† Each odds ratio was adjusted for the other variables in the model. The odds ratios were obtained by taking the exponential of the regression coefficients from the final model.

†Baseline (comparison) categories.

spontaneous abortion was also significant between wives of exposed workers and wives of unexposed workers. Recurrent spontaneous abortions were also associated with exposure to anaesthetics (table 5). Table 6 shows the proportion of recognised pregnancies which ended in abortion before the 20th week. The spontaneous abortion rates for the pregnancies of exposed female nurses and others and wives of exposed male doctors and others were significantly higher than in the controls. This was not the case for exposed female doctors and wives of male nurses.

Further analysis using 10 weeks gestation to differentiate between early and late abortion showed that there was no significant difference in the late abortion rate between all groups. There was, however, a significant difference in the early abortion 
rate similar to the group findings shown in table 6 . The odds ratio for congenital abnormalities with exposure in female workers was significant with an increased risk in younger children. The mother's age at the time of pregnancy was a negative factor for exposed female workers, whereas smoking during pregnancy was an added risk for wives of exposed workers. All anomalies were counted in the analysis. The exposed group reported a significantly higher proportion of minor malformations such as birth marks and naevi.

Analysis of the mode of administration of the questionnaire and other factors such as geographical location or residential district had no effect on the distribution of reported health effects. There was a low response to the question of alcohol consumption during pregnancy, either because of reluctance on the part of the respondent or lack of recollection, particularly in the male respondents $(11.4 \%$ of response). This prevented us from determining the effect of alcohol consumption on the outcome of pregnancy among male respondents. Alcohol consumption during pregnancy in female respondents seemed to be associated with the occurrence of congenital abnormality; it was however, negatively associated with spontaneous abortion (table 4).

Analysis by chi-squared test showed no significant difference between the exposed and the unexposed groups in the frequency of chronic disease (table 7).

Tables 8 and 9 compare the findings of this study

Table 5 Associations between reported reproductive effects and history of anaesthetics exposure controlling for the effects of potential confounders by linear logistic regression among spouses of male workers in selected Ontario hospitals

\begin{tabular}{|c|c|c|c|}
\hline Independent variables & Description & $\begin{array}{l}\text { Adjusted } \\
\text { odds ratio }\end{array}$ & $\begin{array}{l}95 \% \text { Confidence } \\
\text { interval }\end{array}$ \\
\hline $\begin{array}{l}\text { Anaesthetics exposure } \\
\text { Birth order } \\
\text { Age of mother at pregnancy } \\
\text { Cigarette consumption during } \\
\text { pregnancy } \\
\text { Previous spontaneous abortion } \\
\text { Occupation } \\
\text { Occupation }\end{array}$ & $\begin{array}{l}\quad \text { Spontaneous abortion } \\
\text { Exposed/unexposed } \neq \\
\text { One increase } \\
\text { One year increase } \\
\text { Over } 20 \text { cigarettes a day/under } \\
20 \text { cigarettes/none } \\
\text { Yes/no } \\
\text { Doctors/others } \\
\text { Nurses/others }\end{array}$ & $\begin{array}{l}2.30^{\star} \\
1.05 \\
1.01 \\
0.92 \\
1.86^{\star} \\
0.51^{\star} \\
0.85\end{array}$ & $\begin{array}{l}1.68-3.13 \\
0.98-1.13 \\
0.98-1.03 \\
0.78-1.07 \\
1.44-2.39 \\
0.36-0.71 \\
0.47-1.52\end{array}$ \\
\hline $\begin{array}{l}\text { Anaesthetics exposure } \\
\text { Birth order } \\
\text { Age of mother at pregnancy } \\
\text { Cigarette consumption during pregnancy }\end{array}$ & $\begin{array}{l}\text { Congenital abnormality } \\
\text { Exposed/unexposed } \\
\text { One increase } \\
\text { One year increase } \\
\text { Over } 20 \text { cigarettes a day/under } \\
20 \text { cigarettes/none }\end{array}$ & $\begin{array}{l}1 \cdot 46^{\star} \\
0 \cdot 97 \\
1 \cdot 02 \\
1 \cdot 31^{\star}\end{array}$ & $\begin{array}{l}1 \cdot 04-2 \cdot 05 \\
0.88-1.05 \\
0.99-1.05 \\
1 \cdot 10-1 \cdot 55\end{array}$ \\
\hline $\begin{array}{l}\text { Occupation } \\
\text { Occupation }\end{array}$ & $\begin{array}{l}\text { Doctors/others } \\
\text { Nurses/others }\end{array}$ & $\begin{array}{l}0.90 \\
1.29\end{array}$ & $\begin{array}{l}0.57-1 \cdot 42 \\
0.61-2 \cdot 73\end{array}$ \\
\hline
\end{tabular}

${ }^{\star} \mathrm{p}<0.05$.

+ Each odds ratio was adjusted for the other variables in the model. The odds ratios were obtained by taking the exponential of the 3 regression coefficients from the final model.

${ }_{+}^{+}$Baseline (comparison) categories.

Table 6 Spontaneous abortion rates from pregnancies of exposed women and spouses of exposed men

\begin{tabular}{|c|c|c|c|c|c|c|c|c|}
\hline \multirow[b]{2}{*}{ Occupation } & \multicolumn{8}{|c|}{ Rate/100 pregnancies* (Total no of pregnancies) } \\
\hline & \multicolumn{2}{|c|}{ Exposed group } & $S E$ & \multicolumn{2}{|c|}{ Unexposed group } & $S E$ & \multicolumn{2}{|c|}{ Significance } \\
\hline $\begin{array}{l}\text { Doctors } \\
\text { Nurses } \\
\text { Others } \\
\text { Wives of doctors } \\
\text { Wives of nurses } \\
\text { Wives of others }\end{array}$ & \multicolumn{2}{|c|}{$\begin{array}{l}13 \cdot 5(341) \\
16 \cdot 55(3913) \\
22 \cdot 0(229) \\
9 \cdot 3(4736) \\
9 \cdot 6(126) \\
19 \cdot 7(182)\end{array}$} & $\begin{array}{l}2 \cdot 1 \\
0 \cdot 8 \\
3 \cdot 5 \\
0 \cdot 5 \\
2 \cdot 7 \\
3 \cdot 8\end{array}$ & \multicolumn{2}{|c|}{$\begin{array}{c}9 \cdot 2(106) \\
10 \cdot 5(1020) \\
9 \cdot 6(860) \\
3 \cdot 5(848) \\
9 \cdot 7(51) \\
7 \cdot 4(467)\end{array}$} & $\begin{array}{l}3.0 \\
1.4 \\
1.5 \\
0.7 \\
3.8 \\
1.4\end{array}$ & \multicolumn{2}{|c|}{$\begin{array}{l}\text { NS } \\
p<0.05 \\
p<0.05 \\
p<0.05 \\
\text { NS } \\
p<0.05\end{array}$} \\
\hline \multicolumn{9}{|c|}{$\begin{array}{l}\star \text { Standardised for age and smoking. } \\
\mathrm{SE}=\text { Standard error. }\end{array}$} \\
\hline \multicolumn{9}{|l|}{ Table 7} \\
\hline & \multicolumn{2}{|c|}{ Unexposed group } & \multicolumn{3}{|c|}{ Exposed group } & \multicolumn{3}{|c|}{ Random sample } \\
\hline & $\begin{array}{l}\text { Had } \\
\text { effect }\end{array}$ & $\begin{array}{l}\text { Had no } \\
\text { effect }\end{array}$ & $\begin{array}{l}\text { Had } \\
\text { effect }\end{array}$ & $\begin{array}{l}\text { Had no } \\
\text { effect }\end{array}$ & $\begin{array}{l}\text { Odds }{ }^{\star} \text { ratio } \\
\text { ( } p \text { value) }\end{array}$ & $\begin{array}{l}\text { Had } \\
\text { effect }\end{array}$ & $\begin{array}{l}\text { Had no } \\
\text { effect. }\end{array}$ & $\begin{array}{l}\text { Odds ratio } \\
\text { ( } p \text { value) }\end{array}$ \\
\hline $\begin{array}{l}\text { Cancer/leukemia } \\
\text { Liver problem } \\
\text { Kidney problem } \\
\text { Other health problem }\end{array}$ & $\begin{array}{r}41 \\
26 \\
76 \\
530\end{array}$ & $\begin{array}{l}2150 \\
2108 \\
2063 \\
1671\end{array}$ & $\begin{array}{r}122 \\
105 \\
259 \\
1545\end{array}$ & $\begin{array}{l}6168 \\
5906 \\
5782 \\
4781\end{array}$ & $\begin{array}{l}1.03(0.84) \\
1.44(0.09) \\
1.21(0.14) \\
1.01(0.74)\end{array}$ & $\begin{array}{r}18 \\
20 \\
47 \\
333\end{array}$ & $\begin{array}{l}1409 \\
1326 \\
1303 \\
1108\end{array}$ & $\begin{array}{l}0.66(0.15) \\
1.22(0.50) \\
0.97(0.91) \\
0.94(0.50)\end{array}$ \\
\hline
\end{tabular}


Table 8 Comparison of $A S A$ ad hoc committee study with Ontario survey findings (general pregnancy)

\begin{tabular}{|c|c|c|}
\hline & $\begin{array}{l}\text { ASA ad hoc } \\
\text { committee }\end{array}$ & Ontario survey \\
\hline Groups compared & $\begin{array}{l}\text { Operating room } \\
\text { MDs and RNs } v \\
\text { other MDs and RNs }\end{array}$ & $\begin{array}{l}\text { Hospital workers } \\
\text { exposed to } \\
\text { anaesthetics } v \\
\text { hospital workers not } \\
\text { exposed }\end{array}$ \\
\hline $\begin{array}{l}\text { Method of data } \\
\text { collection }\end{array}$ & Mail questionnaire & $\begin{array}{l}\text { Questionnaire with } \\
\text { interview, self } \\
\text { administered or a } \\
\text { combination of both }\end{array}$ \\
\hline Sample size & $\begin{array}{l}29810 \text { exposed; } \\
10234 \text { unexposed }\end{array}$ & $\begin{array}{l}6336 \text { exposed; } 2202 \\
\text { unexposed }\end{array}$ \\
\hline Response rate & $\begin{array}{l}60 \cdot 1^{\circ} \text { exposed; } \\
42 \cdot 8^{\circ} \text { unexposed } \\
\left(54 \cdot 5^{\circ} \text { overall }\right)\end{array}$ & $\begin{array}{l}78.8 \% \text { exposed; } 87.2 \% \\
\text { unexposed }(80.8 \% \\
\text { overall) }\end{array}$ \\
\hline $\begin{array}{l}\text { Pregnancies: } \\
\text { No exposed/ } \\
\text { unexposed }\end{array}$ & $\begin{array}{l}M D s=486 / 308 \\
\mathrm{RNs}=4607 / 1948\end{array}$ & $\begin{array}{l}M D s=5521 / 1093 \\
R N s=4136 / 1116 \\
O T=431 / 1385\end{array}$ \\
\hline $\begin{array}{l}\text { No spontaneous } \\
\text { abortions; } \\
\text { exposed/unex- } \\
\text { posed } \\
\text { Relative risk }\end{array}$ & $\begin{array}{l}\mathrm{MDs}=80 / 27 \\
\mathrm{RNs}=852 / 294 \\
\mathrm{MDs}=2 \cdot 0^{\star} \\
\mathrm{RNs}=1 \cdot 2^{\star}\end{array}$ & $\begin{array}{l}\text { MDs }=576 / 85 \\
\mathrm{RNs}=650 / 143 \\
\mathrm{OT}=72 / 168 \\
\mathrm{MDs}=1 \cdot 4^{\star} \\
\mathrm{RNs}=1 \cdot 3^{\star} \\
\mathrm{OT}=1 \cdot 5^{\star}\end{array}$ \\
\hline $\begin{array}{l}\text { No live births; } \\
\text { exposed/unex- } \\
\text { posed } \\
\text { No congenital } \\
\text { malformations; } \\
\text { exposed/unex- } \\
\text { posed }\end{array}$ & $\begin{array}{l}M D s=384 / 276 \\
\mathrm{RNs}=3690 / 1629 \\
M D s=27 / 7 \\
\mathrm{RNs}=312 / 124\end{array}$ & $\begin{array}{l}\text { MDs }=4910 / 1002 \\
\text { RNs }=3449 / 966 \\
\text { OTs }=346 / 1206 \\
\text { MDs }=280 / 36 \\
\text { RNs }=399 / 75 \\
\text { OT }=32 / 70\end{array}$ \\
\hline Relative risk & $\begin{array}{l}\mathrm{MDs}=2 \cdot 8^{\star} \\
\mathrm{RNs}=1 \cdot 1\end{array}$ & $\begin{array}{l}\mathrm{MDs}=1 \cdot 6^{\star} \\
\mathrm{RNs}=1 \cdot 6^{\star} \\
\mathrm{OT}=1 \cdot 6^{\star}\end{array}$ \\
\hline
\end{tabular}

${ }^{\star} p=0 \cdot 05$.

$\mathrm{MD}=$ Doctors; $\mathrm{RN}=$ registered nurses; $\mathrm{OT}=$ other staff.

with that of the ASA ad hoc committee. Although there was agreement between findings on reproductive outcomes, there was no agreement on chronic effects on health.

\section{Discussion}

In studies of this type, in which subjects are aware of the purpose, some reporting bias by those completing the questionnaires cannot be ruled out. ${ }^{378} \mathrm{~A}$ recall bias was also possible as the history referred to a 20 year span.

Whereas all persons potentially exposed to waste anaesthetic gases were identified by the director of operating room nursing in each of the 75 hospitals, the unexposed persons were randomly chosen from other departments within these hospitals. Criteria such as sex, age, and duration of service were not predetermined but were accounted for in the statistical analysis.

Because of the fear of a low response rate from the large exposed group, one out of every five exposed workers was randomly chosen for vigorous follow up in order to ensure a conclusion from the analysis. The data from the randomly selected exposed population
Table 9 Comparison between ASA ad hoc committee study and Ontario survey findings (disease)

\begin{tabular}{|c|c|c|}
\hline & $\begin{array}{l}\text { ASA ad hoc } \\
\text { committee }\end{array}$ & Ontario survey \\
\hline Groups compared & $\begin{array}{l}\text { Operating room } \\
\text { MDs and RNs } v \\
\text { other MDs and RNs }\end{array}$ & $\begin{array}{l}\text { Hospital workers } \\
\text { exposed to } \\
\text { anaesthetics } v \\
\text { hospital workers not } \\
\text { exposed }\end{array}$ \\
\hline $\begin{array}{l}\text { Total } \\
\text { malignancies: } \\
\text { No men } \\
\text { exposed/No } \\
\text { unexposed }\end{array}$ & $8942 / 2604$ & $2489 / 720$ \\
\hline $\begin{array}{l}\text { Cancers; No } \\
\text { exposed/No } \\
\text { unexposed }\end{array}$ & $75 / 17$ & $58 / 12$ \\
\hline $\begin{array}{l}\text { Relative risk } \\
\text { No women }\end{array}$ & $\begin{array}{l}1 \cdot 3 \\
9258 / 5966\end{array}$ & $\begin{array}{l}1.4 \\
3797 / 1467\end{array}$ \\
\hline $\begin{array}{l}\text { exposed/No } \\
\text { unexposed }\end{array}$ & & \\
\hline $\begin{array}{l}\text { Cancers; No } \\
\text { exposed/No } \\
\text { unexposed }\end{array}$ & $469 / 104$ & $64 / 29$ \\
\hline Relative risk & $1 \cdot 4^{\star}$ & 0.8 \\
\hline $\begin{array}{l}\text { Liver disease: No } \\
\text { men exposed/No } \\
\text { unexposed }\end{array}$ & $8025 / 2423$ & $2404 / 700$ \\
\hline $\begin{array}{l}\text { No diseased; } \\
\text { exposed/un- } \\
\text { exposed }\end{array}$ & $347 / 65$ & $62 / 13$ \\
\hline Relative risk & $\begin{array}{l}1 \cdot 6^{\star} \\
15843 / 5024\end{array}$ & $1 \cdot 4$ \\
\hline $\begin{array}{l}\text { No women } \\
\text { exposed/No } \\
\text { unexposed }\end{array}$ & $15843 / 5024$ & $3604 / 1430$ \\
\hline $\begin{array}{l}\text { unexposed } \\
\text { No diseased; } \\
\text { exposed/un- } \\
\text { exposed }\end{array}$ & $447 / 92$ & $43 / 13$ \\
\hline $\begin{array}{c}\text { Relative risk } \\
\text { Kidney disease: }\end{array}$ & $1 \cdot 5^{\star}$ & $1 \cdot 3$ \\
\hline $\begin{array}{l}\text { Kidney disease: } \\
\text { No men }\end{array}$ & $8108 / 2420$ & $2401 / 704$ \\
\hline $\begin{array}{l}\text { No men } \\
\text { exposed/No } \\
\text { unexposed }\end{array}$ & & \\
\hline $\begin{array}{l}\text { No diseased; } \\
\text { exposed/un- } \\
\text { exposed }\end{array}$ & $330 / 108$ & $85 / 25$ \\
\hline Relative risk & 0.9 & 1.0 \\
\hline $\begin{array}{l}\text { No women } \\
\text { exposed/No } \\
\text { unexposed }\end{array}$ & $16084 / 5556$ & $3636 / 1431$ \\
\hline unexposed & $473 / 115$ & $174 / 51$ \\
\hline & & \\
\hline Relative risk & $1 \cdot 3^{\star}$ & $1 \cdot 4$ \\
\hline
\end{tabular}

and the total exposed population were analysed separately, and no differences in results were found. Therefore, the results for the doctors are deemed to be valid despite the low response rate $(62 \%)$.

The weekly exposure to anaesthetic gases by occupational group was expressed in hours as estimated from a joint hygiene investigation. ${ }^{39}$ This was considered to be the best way of estimating retrospectively the extent of exposure; it does not, however, provide data for a dose effect analysis as it only provides the duration of exposure and not the time weighted average exposure. There is inevitable uncertainty about the exact exposure dose for the occupational groups as no exposure levels had been 
measured in the past. Accordingly, the analysis had to use duration of exposure regardless of the levels of exposure to waste anaesthetic gases. Levels of exposure reported elsewhere indicate that current exposure to halogenated anaesthetics in Ontario hospitals is within the exposure standard of $2 \mathrm{ppm}$; nitrous oxide concentrations were found, however, to exceed $25 \mathrm{ppm}$ in most operating rooms. With the installation of improved scavenging equipment and maintenance this has now been rectified. No attempt was made to correlate the air sampling results with the reported effects on health because these effects could be attributed to earlier exposures in other hospitals.

Unlike results from the ASA study, a relation between exposure to anaesthetics and the incidence of chronic disease (cancer, leukaemia, and liver and kidney disease) was not demonstrated. The results, however, suggested an association between exposure to anaesthetics and adverse reproductive outcomes in exposed women; a significantly increased risk of spontaneous abortion; and more risk of having children with congenital abnormalities. This agrees with findings from the ASA study.

Of concern is the difference between the average abortion rate before the 20th week among unexposed women doctors $(9.2 \%)$ and the rate for the wives of unexposed doctors $(3.5 \%$ ) (table 6 ), which resulted in a significant difference between the wives of exposed and unexposed male respondents. This suggests underreporting by unexposed male physicians in respect of their wives. Alternatively, the difference in abortion rates may imply a significant effect of exposure in the men. This difference agrees with the findings from studies on dentists, ${ }^{1020}$ and exposure to nitrous oxide appears to be a common factor. Furthermore, nitrous oxide was inadequately controlled in Ontario hospitals. ${ }^{39}$

The results on congenital abnormalities must be judged with caution as, again, there may be reporting bias $^{38}$; all reported anomalies were counted, whether trivial or serious, and it is possible that exposed individuals may have reported trivial anomalies that were ignored by unexposed respondents.

In summary, the results show an association between exposure to anaesthetic gases and abnormal pregnancy. It is necessary to be aware of the problem with studies of this type in which the subjects know the purpose; the results may not accurately reflect the effects of exposure as there may be reporting bias. Because of the consistency of the findings noted among different studies, it is obviously important to minimise the circulation of anaesthetic gases in operating and recovery rooms.

We thank, most sincerely, the Ontario Hospital Association; the administration and staff of the participating hospitals for their generous help and participation; and the nurse consultants of the Health and Safety Support Services Branch of the Ministry of Labour for helping in the data collection.

1 Bruce DL, Eide KA, Linde HW, Echkenhoff JE. Causes ¿ of death among anesthesiologists-a 20-year old survey. @) Anesthesiology 1968;29:565-9.

2 Bruce DL, Eide KA, Smith NJ, Seltzer F, Dykes MHM. A $\vec{\circ}$ propsective survey of anesthesiologist mortality 1967-1971. Anesthesiology 1974;41:71-4.

3 Doll R, Peto R. Mortality among doctors in different occupations. Br Med J 1977;i:1433-6.

4 Bruce DL, Bach MJ. Psychologic studies of human performance as affected by traces of enflurane and nitrous oxide. 3 Anesthesiology 1975;42:194-6.

5 Cascorbi HG. Effects of anesthetics on the immune system. In: \pm Cottrell JE, ed. Occupational hazards to operating room and $V$ recovery room personnel. Boston: Little Brown Co 1981:69-75. -

6 Layzer RB, Fishman RA, Schafer JA, Neuropathy following 6 abuse of nitrous oxide. Neurology 1978;28:504-6.

7 Bunker JP, Child CG, Davidson CS, et al. Possible association 음 between anesthesia and postoperative hepatic necrosis. National Academy of Sciences-National Research Council. Summary of the National Halothane Study. JAMA 1966;197:775-88.

8 Dienstag JL. Halothane hepatitis-allergy or idiosyncrasy. N Engl J Med 1980;303:102-4.

9 Cohen EN, Brown BW, Bruce DL, et al. Occupational disease among operating room personnel: a national study. Anesthesiology 1974;41:317-40.

10 Cohen EN, Brown BW, Bruce DL, et al. A survey of anesthetic health hazards among dentists. J Am Dent Assoc 1975;90:1291-6.

11 Corbett TH, Cornell RG, Lieding K, Endres JL. Incidence of cancer among Michigan nurse-anaesthetists. Anesthesiology 1973;38:260-3.

12 Vaisman AJ. Working conditions in surgery and their effects on the health of anesthesiologists. Eksperimentalnaia Khirurgiia $i$ Anesteziologiia (Moskva) 1967;3:44-9.

13 Askrog G, Harvald B. Teratogenic effect of inhalation anesthetics. Nord Med 1970;83:498-504.

14 Cohen EN, Bellvile JW, Brown BW. Anaesthesia, pregnancy and miscarriage-a study of operating room nurses and anesthetists. Anesthesiology 1971;35:343-7.

15 Knill-Jones RP, Moir DD, Rodrigues LV, Spence AA. Anaesthetic practice and pregnancy controlled survey of women anaesthetists in the United Kingdom. Lancet 1972;i:1326-8.

16 Knill-Jones RP, Newman BJ, Spence AA. Anesthetic practice and pregnancy-controlled survey of male anesthetists in the United Kingdom. Lancet 1975;ii:807-9.

17 Pharoah POD, Alberman E, Doyle P. Outcome of pregnancy among women in anesthetic practice. Lancet 1977:i:34-6.

18 Rosenberg P, Kirves A. Miscarriages among operating theatre staff. Acta Anaesthesiol Scand 1973;53(suppl):37-42.

19 Ericson A, Kallen B. Survey of infants born in 1973 or 1975 to Swedish women working in operating rooms during their pregnancies. Anesth Analg 1979;58:302-5.

20 Cohen EN, Brown BW, Wu ML, et al. Occupational disease in $\Omega$ dentistry and chronic exposure to trace anaesthetic gases. N $J$ Am Dent Assoc 1980;101:21-36.

21 Ramazotto LJ, Carlin RD, Warchalowski GA. Effects of nitrous oxide during organogenesis in the rat. J Dent Res

22 Fink BR, Shepard TH, Blandau RJ. Teratogenic activity of $C$ nitrous oxide. Nature 1967;214:146-7.

23 Shepard TH, Fink BR. Teratogenic activity of nitrous oxide in $\mathbb{D}$ rats. In: Fink BR, ed. Toxicity of anesthetics. Baltimore: + Williams and Wilkins, 1968:308-21.

24 Lane GA, Nahrwold ML, Tait AR, Taylor-Busch M, Cohen PJ. Anesthetics as teratogens: nitrous oxide is fetotoxic, xenon is not. Science 1980;210:899-901.

25 National Institution for Occupational Safety and Health. $\overrightarrow{\mathbb{T}}$ Criteria for a recommended standard, occupational exposure to $\varrho$ waste anaesthetic gases and vapours. Washington: United $\sigma$ States Department of Health Education and Welfare, 1977.

26 Smith BE, Gaub ML, Moya F. Teratogenic effects of anesthetic 8 agents: nitrous oxide. Anesth Analg 1965;44:726-32.

27 Shah RM, Burdett DN, Donaldson D. The effects of nitrous 
oxide on the developing hamster embryo. Can J Physiol Pharmacol 1979;51:1229-32.

28 Vieira E. Effect of the chronic administration of nitrous oxide $0.5 \%$ to gravid rats. Brit J Anaesth 1979;51:283-7.

29 Vieira E, Cleaton-Jones P, Austin JC, Moyes DG, Shaw R. Effects of low concentrations of nitrous oxide on rat fetuses. Anesth Analg 1980;59:175-7.

30 Corbett TH, Cornell RG, Endres J, Millard RI. Effects of low concentration of nitrous oxide on rat pregnancy. Anesthesiology 1973;39:299-301.

31 Ross WT Jr, Cardell RR. Effects of halothane on the ultrastructure of rat liver cells. Am J Anat 1972;135:5-22.

32 Chang LW, Dudley AW, Lee YK, Katz J. Ultrastructural studies of the heptocytes after chronic exposure to low levels of halothane. Exp Mol Pathol 1975;23:35-42.

33 Basford AB, Fink BR. The teratogenicity of halothane in the rat. Anesthesiology 1968;29:1167-73.

34 Hughes HC, Lang CM. Hepatitis necrosis produced by repeated administration of halothane to guinea pigs. Anesthesiology 1972;36:466-71.
35 Smith BE, Gaub ML, Moya F. Investigations into the teratogenic effects of anesthetic agents: the fluorinated agents. Anesthesiology 1965;26:260-1.

36 Smith BE, Usubiaga LE, Lehrer SB. Cleft palate induced by halothane anesthesia in C-57 black mice. Teratology 1971;4:242.

37 Axelsson G, Rylander R. Exposure to anesthetic gases and spontaneous abortion response bias in a postal questionnaire study. Int J Epidemiol 1982;11:250-6.

38 Axelsson G, Rylander R. Validation of questionnaire reported miscarriage malformation and birth weight. Int J Epidemiol 1984;13:94-8.

39 Rajhans GS, Brown DA, Whaley DA, Wong L, Guirguis SS. Evaluation of occupational exposure to waste anesthetic gases in Ontario hospitals. Ann Occup Hyg 1989;33:27-45.

Accepted 22 January 1990

\section{Radiograph atlas of pneumoconiosis: Professor Qi-Guoxing}

This unique collection of chest $x$ ray films shows all the classic changes that none of us in the west can hope to see in a lifetime; indeed they would be difficult to find even by an exhaustive search of the film archives of all the departments of occupational chest disease. Each film is quite well reproduced and is accompanied by a diagram showing the relevant abnormalities and a brief note in English as well as in Chinese describing the changes and giving both the occupation of the subject and the International Labour Office classification of the changes shown by the $x$ ray film. Two hundred and sixty seven separate conditions are dealt with in this way and are followed by 80 films showing combinations of conditions and progression. Everyone who is interested in occupational lung disease will enjoy owning this book and will refer to it from time to time. It can be obtained from the author for a draft or international money order for $\$ 30$ plus $\$ 15$ postage to: Professor Qi-Guoxing, Shanxi Provincial Institute of Labour, Health, and Occupational Disease, Taiyuan City 030012, Peoples Republic of China.

Unfortunately the text book on pneumoconiosis by the same author has not been translated into English. P C ELMES Dawros House, St Andrew's Road, Dinas Powys, $S$ Glamorgan CF6 $4 H B$. 